УДК 001.11:[658:005.934

\title{
ЗУБкО Тетяна,
}

к. е. н., докторант, доцент кафедри економіки та фінансів підприємства Київського національного торговельно-економічного університету вул. Кіото, 19, м. Київ, 02156, Україна

E-mail: t.zubko@knute.edu.ua ORCID: 0000-0002-8950-1797

\section{ГЕНЕЗИС ПОНЯТТЯ}

\section{"ЕКОНОМІЧНА БЕЗПЕКА ПІДПРИЕМСТВА"}

Досліджено сутність та еволюичю поняття "економічна безпека". Розглянуто етапи формування категорії "економічна безпека". Систематизовано та згруповано підходи до визначення поняття "економічна безпека підприємства", розкрито його зміст.

Ключові слова: безпека, економічна безпека, економічна безпека підприємства, підходи, види економічної безпеки.

Постановка проблеми. Економічна безпека (ЕБ) в сучасних умовах невизначеності та непередбачуваності є однією 3 найактуальніших тем досліджень і дискусій українських та іноземних економістів. Цьому сприяли терористичні акти, російська військова агресія проти України і анексія Криму. Нестабільна політична і соціально-економічна ситуація в будь-якій країні посилюють ступінь ризику прийняття рішень і функціонування підприємств загалом.

На первинному етапі теоретичних досліджень першочерговим постає необхідність грунтовно дослідити еволюцію саме поняття "Економічна безпека підприємства" (ЕБП).

Аналіз останніх досліджень і публікацій. Проблема економічної безпеки підприємства є однією з актуальних тем наукових дискусій. Питаннями економічної безпеки на мікрорівні займаються такі автори, як: В. Дикань, К. Божко, М. Копитка, В. Лук'янову, М. Кабрік, С. Лекаря, Р. Скриньковський, І. Стояненко, О. Ареф'єв, О. Ілляшенко, Н. Гуляєв [1-11] та ін. Однак попри значний інтерес вітчизняних та зарубіжних вчених і практиків, ще досі не розроблено єдиного підходу до визначення терміна "економічна безпека підприємства", а існуючі підходи відрізняються певними акцентами на ресурсних обмеженнях.

Мета статті - дослідити етапи формування категорії "економічна безпека", виокремити підходи до визначення економічної безпеки та розкрити суть поняття "економічна безпека підприємства".

Матеріали та методи. Основою цієї статті є синтез результатів досліджень вітчизняних та зарубіжних науковців щодо визначення категорій "економічна безпека" i "економічна безпека підприємства". Дослідження цього питання проведено із застосуванням методів теоретичного узагальнення, аналізу і синтезу.

\footnotetext{
(C) Зубко Т., 2021
}

ISSN 1727-9313. ВICHИК КНТЕУ. 2021. № 
Результати дослідження. Людство ще 3 давніх часів відчувало негативний вплив навколишнього середовища. Формою зменшення впливу різних загроз став захист, безпека. Історично склалося, що для людини поняття "безпека" двовимірне: людина почувається безпечно, якщо відчуває захист у певний момент часу або якщо має впевненість у майбутньому. Згадки про термін "безпека" зустрічаються навіть у Біблії у значенні стану захисту від небезпеки.

Розуміння економічної безпеки фактично виникло з появою держави та входить до складової національних інтересів. Згадки про доцільність підтримки безпеки в економічному контексті є в праці Платона "Політея". В цьому творі філософ запропонував ідею стану "ідеальної держави", яка перебуває в безпеці.

Ще одним історичним документом, який засвідчує вживання цього терміна, є словник Робера від 1190 р., в якому безпеку розглянуто як спокійний стан духу людини, захищеність від будь-якої небезпеки.

На думку сучасних учених, категорія "безпека" у слов'янському суспільстві з'явилась у середині XV ст. як реакція на загарбницькі зазіхання Золотої Орди. У XVII ст. це поняття вже відносять до державних, зокрема у серпні 1881 р. в Росії прийнято "Положення про заходи щодо охорони державного порядку і громадського спокою", де визначено поняття громадської безпеки.

У XVII-XVIII ст. поняття "безпека" стосувалось здебільшого питань природного права (Т. Гоббс, Д. Локк, К. Гельвецій, П. Гольбах та ін.). У той час поняття безпеки прямо пов'язувалося з існуванням держави. Тому термін отримує таке трактування: "стан, ситуація спокою, яка виникає в результаті відсутності реальної небезпеки (як фізичної, так і моральної), а також матеріальні, економічні, політичні умови, відповідні органи, які сприяють утворенню такої ситуації" [1;2].

Ще А. Сміт у своїй праці "Дослідження про природу і причини багатства народів" базував власні дослідження на вивченні економічного розвитку суспільства та підвищення добробуту його населення. Він стверджував, що "щорічна праця кожного народу являє собою первісний фонд, який надає йому всі необхідні для існування і зручностей життя продукти" [3].

Із загостренням у XX ст. кризових явищ посилилася увага до питань економічної безпеки держави. Зокрема, в процесі пошуку рішень стосовно виходу з кризи 1929-1933 рр. президентом США Ф. Рузвельтом вперше використано поняття "економічна безпека". У 1934 р. створено комітет з економічної безпеки, метою якого була нормалізація і стабілізація економічної та соціальної ситуації у державі.

У Сполучених Штатах Америки 26 липня 1947 р. президент Г. Трумен підписав "Акт про національну безпеку", в якому принципом міжнародної політики визначено саме Концепцію національної безпеки. Ще один президент США Б. Клінтон створив національний економічний 
комітет для розробки та впровадження заходів з підтримки національної економічної безпеки. В той час поняття ЕБ стосувалося винятково національного рівня, а не рівня підприємств. Це прослідковується у визначеннях американських та англійських науковців (табл. 1).

Таблиия 1

Визначення безпеки американськими та англійськими науковцями

\begin{tabular}{|c|c|}
\hline Автор, рік & Визначення \\
\hline $\begin{array}{l}\text { Волтер Ліпмен } \\
(1943)\end{array}$ & $\begin{array}{l}\text { "Нація знаходиться у безпеці, якщо вона не вимушена жертвувати своїми } \\
\text { законними інтересами для уникнення війни, та в змозі, якщо доведеться, } \\
\text { підтримати їх у ході війни" }\end{array}$ \\
\hline $\begin{array}{l}\text { Арнольд } \\
\text { Вольфер (1962) }\end{array}$ & $\begin{array}{l}\text { "Безпека, в об’єктивному значенні, оцінює відсутність загроз головним } \\
\text { цінностям, в суб'єктивному значенні, відсутність страху з приводу того, } \\
\text { що на ці цінності хтось буде зазіхати" }\end{array}$ \\
\hline $\begin{array}{l}\text { Міжнародна } \\
\text { енциклопедія } \\
\text { соціальних } \\
\text { наук (1968) }\end{array}$ & $\begin{array}{l}\text { "Безпека - це здатність нації захистити свої внутрішні цінності від } \\
\text { зовнішніх загроз" }\end{array}$ \\
\hline $\begin{array}{l}\text { Амос Джордан, } \\
\text { Уільям Тейлор } \\
(1981)\end{array}$ & $\begin{array}{l}\text { "Національна безпека, однак, має більш широке значення ніж захист від } \\
\text { можливої фізичної шкоди; це також включає захист у широкому значенні } \\
\text { життєво важливих економічних та політичних інтересів, втрата яких може } \\
\text { зашкодити фундаментальним цінностям та життєздатності країни" } \\
\end{array}$ \\
\hline $\begin{array}{l}\text { Річард Улман } \\
(1983)\end{array}$ & \begin{tabular}{|l} 
"...один із шляхів переходу до більш всеосяжного визначення безпеки - \\
це запитати, від чого можна було б відмовитись і отримати більше безпеки..."
\end{tabular} \\
\hline $\begin{array}{l}\text { Чарльз Майєр } \\
(1990)\end{array}$ & $\begin{array}{l}\text { "Національна безпека... найкращим чином визначається як здатність контро- } \\
\text { лювати ті внутрішні та зовнішні умови, які, на думку громадськості, } є \text { необхід- } \\
\text { ними для їх власного самовизначення або автономії, процвітання та благополуччя" }\end{array}$ \\
\hline Неу Ц.Р. (1994) & $\begin{array}{l}\text { "Економічна безпека - це здатність захищати або просувати економічні } \\
\text { інтереси США, враховуючи дії, які можуть загрожувати або блокувати } \\
\text { ці інтереси" }\end{array}$ \\
\hline $\begin{array}{l}\text { Девід Ей. } \\
\text { Белдвін (1997) }\end{array}$ & $\begin{array}{l}\text { "Визначення поняття "безпека" нещодавно перетворилося на щось на зразок } \\
\text { поверхової будови. Більшість таких зусиль, однак, більше стосується пере- } \\
\text { гляду політичних програм національних держав, ніж самої концепції безпеки. } \\
\text { Часто це приймає форму пропозицій щодо надання пріоритету таким питан- } \\
\text { ням, як права людини, економіка, навколишнє середовище, наркотрафік, } \\
\text { епідемії, злочинність або соціальна несправедливість, на додаток до тради- } \\
\text { ційної стурбованості безпекою від зовнішніх військових загроз. Такі пропо- } \\
\text { зиції, як правило, підкріплюються сукупністю нормативних аргументів } \\
\text { щодо того, які цінності, яких людей чи груп людей слід захищати, емпірич- } \\
\text { них аргументів щодо характеру та величини загроз цим цінностям" }\end{array}$ \\
\hline $\begin{array}{l}\text { Б. Бузан, } \\
\text { О. Вейєр та } \\
\text { Дж. Ді Вайлд } \\
(1998)\end{array}$ & $\begin{array}{l}\text { Дотримуючись переважно нейтральної позиції, обговорюють основні проблеми, } \\
\text { пов'язані з правомірністю розгляду фірми як об’єкта безпеки, а точніше, } \\
\text { об’єкта економічної безпеки. } \\
\text { "Сам економічний аспект у поєднанні з безпекою вже має високий ступінь } \\
\text { політизації", стверджує Бузан. Бузан здебільшого говорив про сек’юритиза- } \\
\text { цію фірми з позиції держави. Визначають економічну безпеку підприємства } \\
\text { як організаційну безпеку фірми, оскільки "фірми рідко мають сильну пре- } \\
\text { тензію на право виживання" }\end{array}$ \\
\hline
\end{tabular}

Джерело: згруповано за [4; 5; 12-15].

Інша ситуація з означенням ЕБ склалася серед економістів Свропейського Союзу, де термін "економічна безпека" має два тлумачення. Перше належить до позиції ЄС у світовій економічній системі. Найбільшою 
офіційною організацією, що займається комплексними питаннями, в тому числі економічної безпеки в Європі, є Організація з безпеки та співробітництва в Європі (ОБСЄ). Вона об'єднує 57 країн, які розташовані в Європі, Центральній Азії та Північній Америці. 31973 по 1975 рр. проводилися "наради з безпеки і співробітництва в Свропі", створені за ініціативи СРСР і соціалістичних держав Свропи, які названі згодом "Гельсінські угоди". У ході проведених форумів ухвалювалися заходи щодо зміцнення економічної безпеки в Свропі. Серед учасників налічувалося 33 європейських держави, США і Канада. Нарада проводилася в три етапи і завершилася підписанням Заключного акта 3 безпеки і співробітництва в Європі. Друге тлумачення передбачає розгляд економічної безпеки саме стосовно підприємств.

На Заході термін "економічна безпека" з'явився завдяки загостренню проблеми обмеженості ресурсів, коли традиційні зв'язки між постачальниками ресурсів, які були життєво необхідні індустріальним країнам, зруйновані через розпад колоніальної системи [16]. У той час концепція ЕБ формувалась під впливом взаємозалежності країн світу, в межах якої поняття економічної безпеки включало активізацію міжнародних господарських зв'язків, перебудову їх на основі врахування інтересів усіх сторін та рівноправ'я.

З 1977 по 2010 рр. відбулася низка зустрічей, в результаті яких підписані такі документи, як: Паризька хартія для нової Свропи, Договір про звичайні збройні сили в Європі (ДЗЗСЄ), прийнята Спільна декларація 22 держав (членів НАТО і ОВД), Хартія європейської безпеки, Угода про адаптацію ДЗЗСЄ, підсумкова Політична декларація і модернізований Віденський документ щодо заходів довіри як основи подальшої роботи.

Iз 80-х років XX ст. розпочалася масштабна наукова розробка категорії "безпека" установами провідних країн світу, найбільш відомі 3 них - Лондонський інститут стратегічних досліджень, Стокгольмський інститут досліджень безпеки.

У міжнародній практиці поняття "економічна безпека" з'явилося у 1980-ті роки, а утвердилося і стало загальновизнаним з прийняттям 40-ю сесією ГА ООН (1985р.) резолюції "Міжнародна економічна безпека". Важливі аспекти забезпечення економічної безпеки держави як основи іiі національної безпеки закріплені у Стратегічній програмі ООН "Цілі тисячоліття" [6, с. 190].

Наведені матеріали свідчать про те, що поняття ЕБ не є сталим, воно змінюється, розширюється. До нього входять ознаки забезпечення існування як окремого підприємства, так і країни, а нині - й об'єднання країн. Основні етапи розвитку поняття "економічна безпека" надано в табл. 2. 
Таблиия 2

Важливі етапи розвитку поняття "економічна безпека"

\begin{tabular}{|c|c|}
\hline Етап & Мета \\
\hline $\begin{array}{l}\text { Прийняття закону "Про національну безпеку" } \\
\text { (США, } 1934 \text { р.) та створення Федерального } \\
\text { комітету з економічної безпеки }\end{array}$ & $\begin{array}{l}\text { Збереження економічної самостійності країни; підви- } \\
\text { щення рівня якості життя населення через забезпе- } \\
\text { чення достатності енергетики та недопущення } \\
\text { енергетичної кризи }\end{array}$ \\
\hline $\begin{array}{l}\text { Створення міжнародних асоціацій забезпечення } \\
\text { міжнародної економічної безпеки розвинених } \\
\text { країн світу (1940-1950 рр.) }\end{array}$ & $\begin{array}{l}\text { Зміцнення безпеки світового господарства та еконо- } \\
\text { міки окремих держав через недопущення енерге- } \\
\text { тичної кризи }\end{array}$ \\
\hline $\begin{array}{l}\text { Прийняття країнами Західної Свропи Стратегії } \\
\text { економічного методу забезпечення національної } \\
\text { безпеки (1973-1975 рр.) } \\
\end{array}$ & $\begin{array}{l}\text { Розробка комплексу заходів із забезпечення сталого } \\
\text { розвитку економіки створенням механізму протидії } \\
\text { внутрішнім і зовнішнім загрозам країнам Свропи }\end{array}$ \\
\hline $\begin{array}{l}\text { Декларування принципів міжнародної безпеки } \\
\text { ООН (1985 р.) в резолюції "Міжнародна } \\
\text { економічна безпека", Прийняття Стратегічної } \\
\text { програми ООН "Цілі тисячоріччя" } \\
\end{array}$ & $\begin{array}{l}\text { Забезпечення комплексного підходу до вирішення } \\
\text { багатьох взаємопов’язаних міжнародних проблем } \\
\text { та стосунків }\end{array}$ \\
\hline $\begin{array}{l}\text { Зміна курсу країн колишнього Радянського Союзу } \\
\text { на формування ринкової системи господарювання } \\
\text { (1991р.) }\end{array}$ & $\begin{array}{l}\text { Демократизація суспільства, подолання соціальної } \\
\text { напруги, забезпечення політичних змін, становлення } \\
\text { ринкової економіки, покращення рівня життя } \\
\text { населення }\end{array}$ \\
\hline $\begin{array}{l}\text { Прийняття країнами колишнього Радянського } \\
\text { Союзу державних нормативно-правових актів } \\
\text { з питань забезпечення національної економічної } \\
\text { безпеки (1993-1994р.) } \\
\end{array}$ & $\begin{array}{l}\text { Формування механізму забезпечення життєво } \\
\text { важливих інтересів особи, суспільства і держави } \\
\text { від внутрішніх і зовнішніх загроз }\end{array}$ \\
\hline $\begin{array}{l}\text { Прийняття програмно-цільових документів } \\
\text { iз забезпечення національної безпеки України } \\
\text { (1997 р.), зокрема у Постанові "Про концепцію } \\
\text { (основи державної політики) національної безпеки } \\
\text { України", схваленій Верховною Радою України } \\
\text { 16.01.1997 р. }\end{array}$ & $\begin{array}{l}\text { Формування сприятливого і передбачуваного } \\
\text { правового поля для розвитку підприємництва } \\
\text { і реалізації права на підприємницьку діяльність; } \\
\text { забезпечення демократизації суспільства, } \\
\text { поліпшення добробуту громадян, формування } \\
\text { цивілізованого конкурентного середовища }\end{array}$ \\
\hline $\begin{array}{l}\text { Гарантування національної безпеки, економічна } \\
\text { безпека позиціонується як одна із стратегічно } \\
\text { важливих їі функціональних складових } \\
\text { (2003-2007 рр.) }\end{array}$ & $\begin{array}{l}\text { Переорієнтація на забезпечення економічної } \\
\text { безпеки держави, для чого були внесені зміни } \\
\text { до Конституції України, затверджені Закони України } \\
\text { "Про основи національної безпеки України", } \\
\text { "Про раду національної безпеки і оборони" } \\
\end{array}$ \\
\hline $\begin{array}{l}\text { Декларування принципів стратегічної значущості } \\
\text { національної безпеки України (2008-2015 рр.). } \\
\text { Фахівцями Національного інституту стратегічних } \\
\text { досліджень під керівництвом академіка НАНУ } \\
\text { В. Горбуліна розроблена "Стратегія національної } \\
\text { безпеки України , затверджена Указом Президента } \\
\text { України № 287/2015 "Про рішення Ради } \\
\text { національної безпеки і оборони України } \\
\text { від } 6 \text { травня } 2015 \text { року "Про Стратегію національної } \\
\text { безпеки України" }\end{array}$ & $\begin{array}{l}\text { Забезпечення такого рівня національної безпеки, } \\
\text { який би гарантував поступальний розвиток України, } \\
\text { іiі конкурентоспроможність, забезпечення прав } \\
\text { і свобод людини і громадянина, подальше зміцнення } \\
\text { міжнародних позицій та авторитету Української } \\
\text { держави у сучасному світі }\end{array}$ \\
\hline $\begin{array}{l}\text { Прийняття стратегічних документів, зокрема } \\
\text { Стратегія сталого розвитку "Україна - 2020" } \\
\text { (Основні положення); Стратегія національної } \\
\text { безпеки України; Концепція боротьби } 3 \\
\text { тероризмом; Воєнна доктрина України та ін. } \\
\text { Базовим законом у сфері національної безпеки } \\
\text { встановлено Закон України "Про національну } \\
\text { безпеку України" від } 21 \text { червня } 2018 \text { р. } \\
\text { (2014-2018 рр.) }\end{array}$ & $\begin{array}{l}\text { Зміцнення стратегії сталого розвитку України, } \\
\text { впровадження нових програм заходів проти } \\
\text { тероризму та сепаратизму }\end{array}$ \\
\hline $\begin{array}{l}\text { Розвиток інтеграційних процесів, зокрема } \\
\text { збільшення впливу євроінтеграції на соціально- } \\
\text { економічний стан країни (теперішній час). } \\
\text { 02.09.2020 р. уряд ухвалив рішення створити } \\
\text { комісію з питань координації виконання } \\
\text { Угоди про асоціацію з ЄС, у керівництво якої } \\
\text { увійдуть також представники Верховної Ради } \\
\text { та Офісу Президента України }\end{array}$ & $\begin{array}{l}\text { Підготовка пропозицій щодо розвитку відносин } \\
\text { з ЄС у сфері європейської інтеграції з урахуванням } \\
\text { поточного стану співробітництва з ЄС та подання } \\
\text { їх Кабінету Міністрів України; підготовки та прове- } \\
\text { дення переговорів/ведення діалогу із стороною ЄС } \\
\text { щодо виконання Угоди про асоціацію }\end{array}$ \\
\hline
\end{tabular}

Джерело: згруповано та доповнено за [3; 4; 7].

ISSN 1727-9313. ВІСНИК КНТЕУ. 2021. 
Економічна безпека є універсальною категорією, яка показує захищеність суб'єктів соціально-економічних відносин на всіх рівнях, починаючи 3 держави й завершуючи окремим суб'єктом господарювання, підприємством, кожним громадянином. На цей час розрізняють такі рівні економічної безпеки $[1$, с. $151 ; 2 ; 4 ; 8 ; 16]$ : глобально-цивілізаційний, міжнародний, національний, регіональний, безпека підприємства, безпека особистості.

Економічну безпеку підприємства становлять юридичні, виробничі відносини і організаційні зв'язки, матеріальні й інтелектуальні ресурси, що забезпечують стабільність його функціонування, фінансовокомерційний успіх, прогресивний науково-технічний і соціальний розвиток.

Досі немає єдиного підходу до визначення сутності, змісту і методів визначення поняття "економічна безпека підприємства". Упродовж останніх десятиліть суттєво змінювались погляди щодо тлумачення цього поняття, що в результаті дає змогу згрупувати низку підходів за такими критеріями: об'єктом дослідження; домінуючим підходом до управління; акцентом на окремих складових; чинниками функціонування (рисунок).

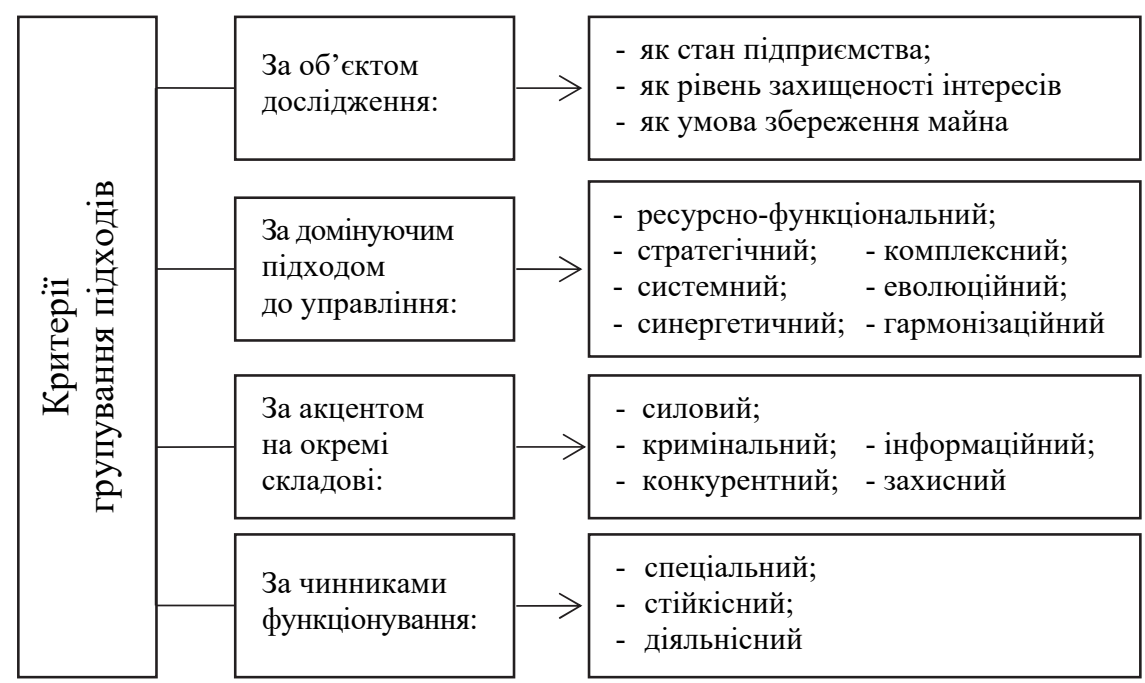

Систематизація змістовних підходів до визначення поняття економічної безпеки підприсмства

Джерело:розроблено автором.

Підходи різняться залежно від того, який акцент діяльності підприємства вони застосовують як головний. Детальний компаративний аналіз дав змогу систематизувати їх та визначити, що найкращими для визначення змісту поняття ЕБ є системно-комплексний та ресурсно-функиіональний підходи.

Характеристику наукових підходів до визначення економічної безпеки підприємства надано в табл. 3. 


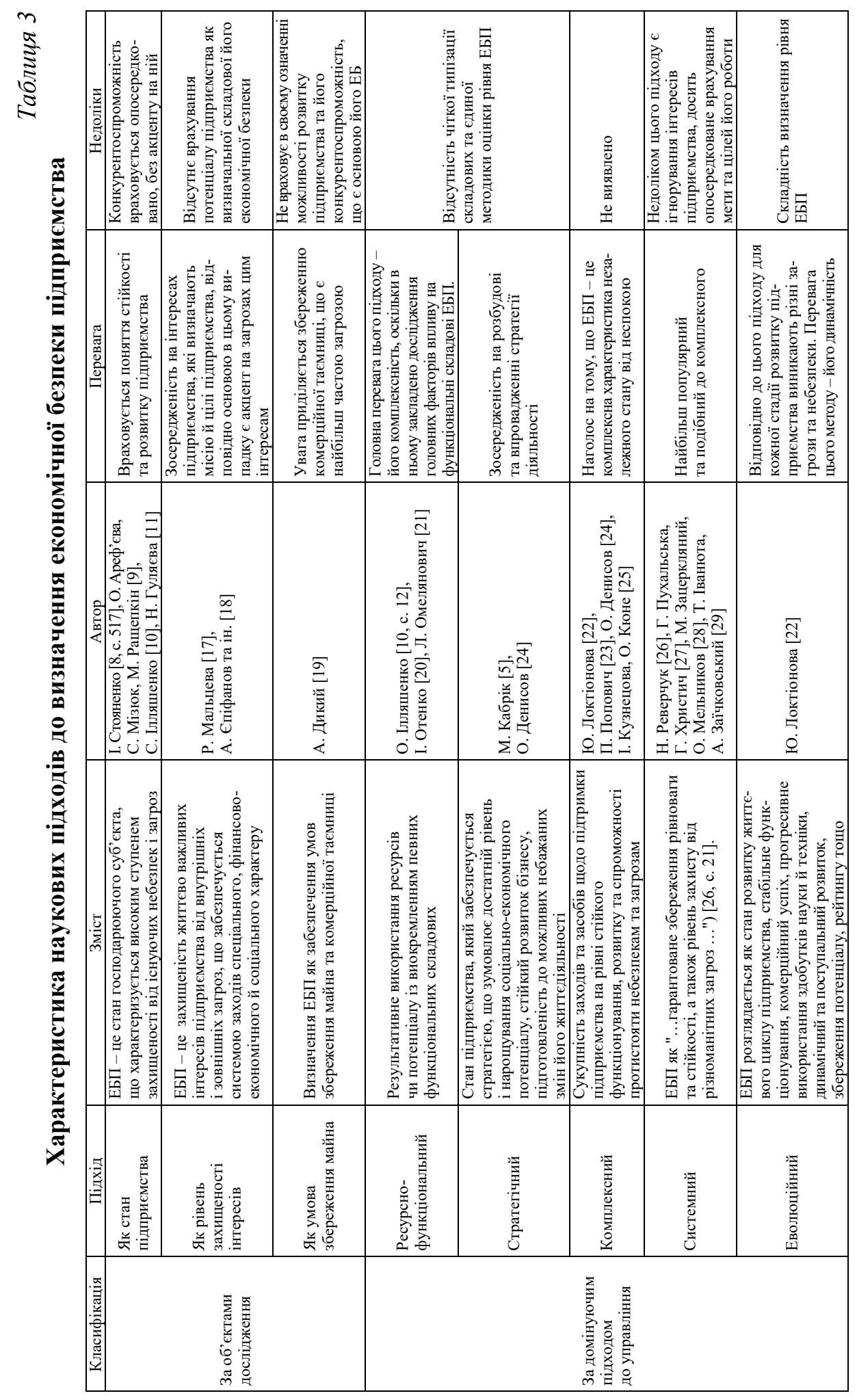




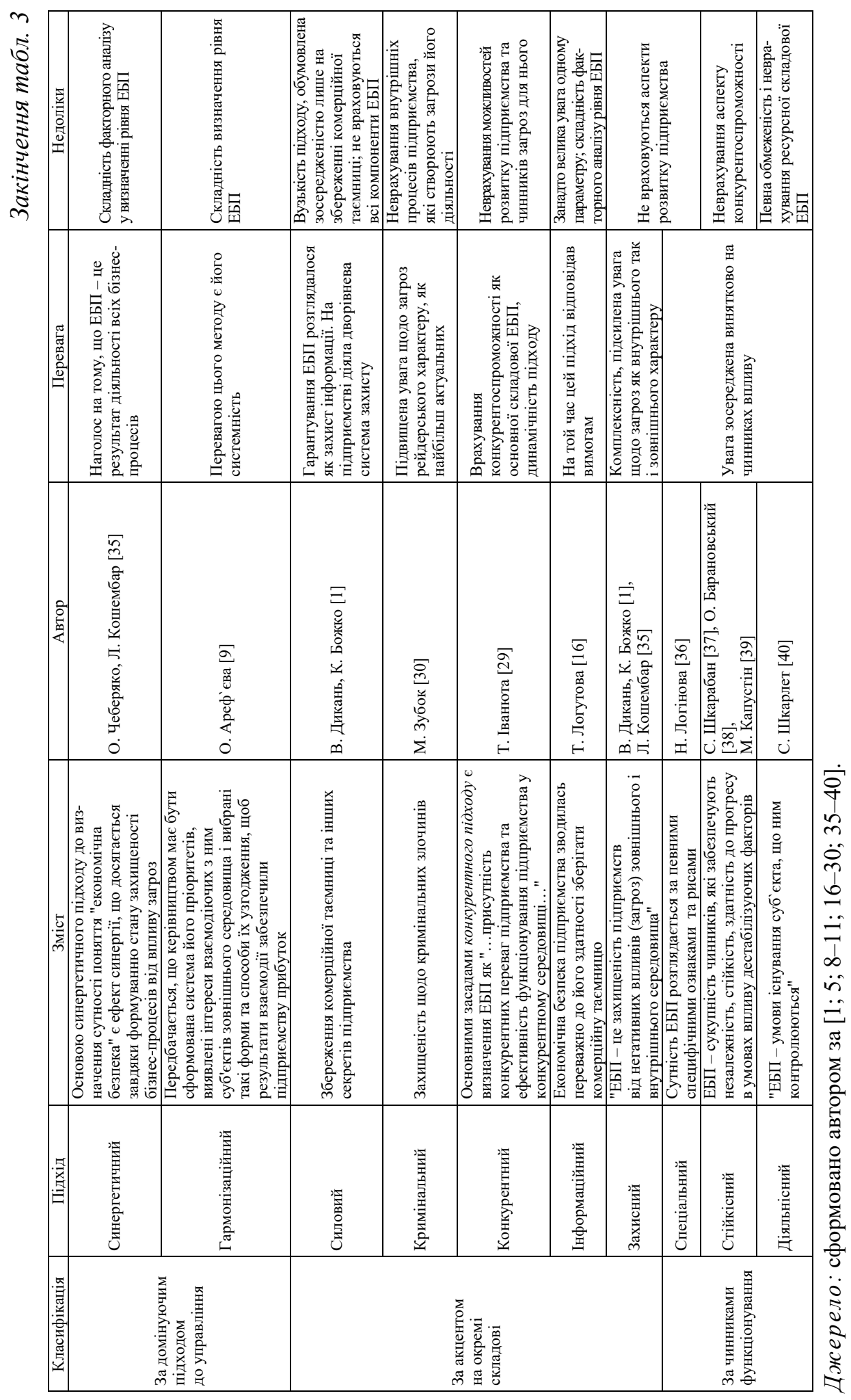


Більшість вітчизняних дослідників наголошують на класифікації за домінуючим підходом до управління, відповідно виділяючи такі: ресурсно-функціональний; стратегічний; комплексний; системний; еволюційний; синергетичний; гармонізаційний. Подібна класифікація найбільш доцільна, оскільки рівень ЕБП визначається завжди суто з метою управління.

Запропоновано оптимальне визначення ЕБП: економічна безпека підприємства - ие стан підприємства, при якому воно є конкурентоспроможним, ефективно використовує свій потенціал та стійко розвивається. У цьому визначенні враховано властивість динамічності (розвиток), ресурсну складову (потенціал), основний критерій оцінки діяльності підприємства - його конкурентоспроможність.

Узагальнення, аналіз та систематизація наявних підходів та визначень поняття економічної безпеки підприємства надали можливість виокремити основні сутнісні характеристики цього поняття:

- стан ефективного використання ресурсів;

- здатність до нейтралізації загроз;

- спроможність до розвитку;

- адаптивність;

- здатність досягати цілі.

До цього переліку доцільно додати ще дві характеристики: opiєнтація на конкурентоспроможність (тобто прагнення забезпечити якнайвищий рівень конкурентоспроможності підприємства); потенщіалоnідтримання (тобто орієнтація на збільшення всіх компонентів потенціалу підприємства).

Висновки. Сформульовано визначення економічної безпеки підпри$\epsilon м c т в а$ з головним акцентом на його конкурентоспроможність, з урахуванням здатності до розвитку та підтримання ресурсного потенціалу. Досліджено підходи до визначення сутності, природи та особливостей ЕБП. Зважаючи на широкий спектр трактувань і різноманітність підходів, визначено, що саме використання двох взаємодоповнюючих підходів (стратегічного та комплексного) обгрунтовує визначення поняття ЕБП. Доповнено наявні на сьогодні сутнісні характеристики досліджуваної дефініції.

У перспективі питання забезпечення достатнього рівня економічної безпеки підприємств та стратегій їх розвитку повинні стати об'єктом більш грунтовного і повного дослідження. Можливості системного аналізу при цьому мають бути поєднані з перевагами традиційного макро- і мікроекономічного аналізу, що дасть змогу суттєво підвищити їх значення.

\section{СПИСОК ВИКОРИСТАНИХ ДЖЕРЕЛ}

1. Дикань В. Л., Божко К. М. Стратегія забезпечення економічної безпеки промислових підприємств. Вісник економіки транспорту і промисловості. 2018. № 63. C. 150-158. URL: http://nbuv.gov.ua/UJRN/Vetp_2018_63_20. 
2. Копитко М. I. Економічна безпека підприємств 3 виробництва транспортних засобів: монографія. Київ: Ліга-Прес, 2015. 556 с.

3. Сміт А. Дослідження про природу і причини багатства народів. Київ: Наш формат, 2018. $736 \mathrm{c}$.

4. Лук'янова В. В. Діагностика економічної безпеки підприємства. Хмельницький: ХНУ, 2014. 165 с.

5. Cabric M. Corporate Security Management: Challenges, Risks, and Strategies. Butterworth-Heinemann, 2015.

6. Лекарь С. Правове регулювання економічної безпеки в Україні. Підприємнищтво, господарство і право. 2019. №12. C. 186-193. URL: http://pgp-journal.kiev.ua/ archive/2019/12/36.pdf; DOI https://doi.org/10.32849/2663-5313/2019.12.35.

7. Скриньковський Р. М. Економічна безпека підприємства: сутність, класифікація та система діагностики. Миколаївський національний університет ім. В. О. Сухомлинського. 2015. Вип. 3. С. 414-418.

8. Стояненко I. В., Лубенець А. О. Вплив діджиталізації на діяльність та економічну безпеку підприємств торгівлі. Молодий вчений. 2019. № 1(65). C. 516-519.

9. Ареф’єва О. В., Мізюк С. Г., Ращепкін М. Д. Особливості формування економічного потенціалу підприємств із позицій економічної безпеки. Науковий вісник Ужгородського національного університету. 2018. Вип. 22. Ч. 1. C. 5- 9. URL: http://www.visnyk-econom.uzhnu.uz.ua/archive/22_1_2018ua/3.pdf.

10. Ілляшенко О. В. Побудова системи економічної безпеки підприємства: принципові положення. Technology audit and production reserves. 2015. № 5/6(25). C. 4-7. URL: http://journals.uran.ua/tarp/article/download/51252/47246 DOI: $10.15587 / 2312-8372.2015 .51252$.

11. Гуляєва Н. М., Вавдійчик I. М. Економічна безпека та стабільне функціонування підприємства. Вісник Київського національного торговельно-економічного університету. 2017. № 4(114). С. 79-88.

12. Baldwin D. A. The Concept of Security. Review of International Studies. 1997. № 23. C. 5-26.

13. Buzan B., Waever O., Wilde de J., Security: A New Framework for Analysis. Google Books. Lynne Rienner Publishers, 1998.

14. Neu C. R. The Economic Dimensions of National Security. 1994. RAND. C. 86.

15. Richard H. Ullman, 'Redefining Security', International Security. 1983. № 8. P. 129-153. URL: https://muse.jhu.edu/article/446023/summary.

16. Логутова Т. Г., Камышникова В. Э. Экономическая безопасность промышленных предприятий. М-во образования и науки Украины, Гос. высшее учеб. заведение "Приазов. гос. техн. ун-т". Мариуполь: ГВУЗ "ПГТУ", 2013. 230 с.

17. Мальцева Р. Ю. Фінансова безпека підприємства: теорія питання. Науковий вісник Чернівеиького торговельно-економічного інституту КНТЕУ. Чернівці: Ант Лтд., 2004. Вип. II. С. 158-65.

18. Єпіфанов А. О., Пластун О. Л., Домбровський В. С. та ін. Фінансова безпека підприємств і банківських установ: монографія; за заг. ред. А. О. Єпіфанова. Суми: УАБС НБУ, 2009. 295 с.

19. Дикий А. П. Організація бухгалтерського обліку як інструмент забезпечення економічної безпеки підприємства: автореф. дис. ... канд. екон. наук: спец. 08.00.09. Житомир: ЖДТУ, 2009. 21 с.

20. Отенко І. П., Іващенко Д. К. Воронков Г. А. Економічна безпека підприємства: навч. посіб. Харків: ХНЕУ, 2012. 252 с. 
21. Омелянович Л. О., Долматова Г. С. Економічна безпека торговельного підприємства; Донецький держ. ун-т економіки і торгівлі ім. М.ТуганБарановського. Донецьк: ДонДУЕТ, 2005. 196 с.

22. Локтионова Ю. А. Механизм идентификации состояний экономической безопасности предприятия. Журнал Социально-экономические явления и прочессыл. Вып. № 5(051). 2013. С. 129-133.

23. Попович П. Економічна безпека підприємства на сучасному етапі розвитку економіки України. Вісник Тернопільської академії народного господарства. 2002. Вип. 2. С. 93-96.

24. Денисов О. С. Комплексний підхід до оцінювання економічної безпеки галузі в умовах глобалізації. Бізнес Інформ. 2018. № 1. С. 207-212. URL: http://nbuv.gov.ua/UJRN/binf_2018_1_31.

25. Кузнецова I., Кюне О. Сучасні підходи до визначення економічної безпеки підприємства. Вісник Одеського наиіонального економічного університету. Вип.1, 2016. С. 122-135. URL: http://dspace.oneu.edu.ua/jspui/bitstream/ 123456789/5246/1/\%Сучасні\%20підходи\% 20до\%20визначення\%20економічноі\% 20безпеки\%20підприємства.pdf

26. Реверчук Н. Й. Управління економічною безпекою підприємницьких структур: монографія. Львів: ЛБІ НБУ, 2004. 195 с.

27. Пухальська Г. В., Христич Г. О. Економічна безпека підприємства: сутність та ії складові. Вісник Хмельницького наџіонального університету. Економічні науки. 2008. № 6. Т.1. С. 197-200.

28. Зацеркляний М. М., Мельников О.Ф. Основи економічної безпеки: навч.посіб. Київ: КНТ, 2009. 337с.

29. Іванюта Т. М., Заїчковський А. О. Економічна безпека підприємства: навч. посіб. Київ: Центр учбової літератури, 2009. 256 с.

30. Крегул Ю. І., Зубок М. І., Банк Р. О. Комерційна розвідка та внутрішня безпека на підприємстві]: навч. посіб.; за ред. Ю. І.Крегула. Київ: Київський національний торговельно-економічний університет, 2014. 175 с.

31. Верхоглядова Н. І., Герасимова О. Л. Щеглова О. Ю., Левчинський Д. Л. Економічна діагностика. Дніпропетровськ: Свідлер, 2011. 332 с.

32. Нусінова О. В. Основи оцінки економічної безпеки підприємств: теоретичні та практичні аспекти. Київ: ПанТот, 2012. 411 с.

33. Caralli R. F., Wilson W. R. The Challenges of Security Management. Pittsburg: CERT. Software Engineering Institute Carnegie Mellon University, 2001. URL: http://www/cert.org/archive/pdf/ESM_challenges.pdf.

34. Андрушків Б. М., Малюта Л. Я., Погайдак О. Б. Адаптивна структурнокомпонентна модель забезпечення економічної безпеки підприємства. Економічний аналіз. 2016. Т. 25. № 2. C. 42-50. URL: http://nbuv.gov.ua/ UJRN/ecan $2016 \quad 25 \% 282 \% 297$.

35. Чеберяко О. В., Кошембар Л. О. Методологічні засади оцінювання економічної безпеки підприємства: зб. наук. пр.; О. Яценко (голов. ред.). Київ: КНЕУ, 2019. Вип. 20. С. 156-175.

36. Логінова Н. I. Місце кадрової безпеки в економічній безпеці підприємства. Коммунальное хазяйство городов. 2009. № 87. С. 371-376.

37. Шкарабан С. І., Корецький Б. М., Ярощук О. В. Діагностика і прогнозування фінансово-господарського розвитку акціонерного товариства: монографія. Терноп. нац. екон. ун-т. Вид. 2-е. Тернопіль: ТАЙП: Рада, 2010. 300 с.

ISSN 1727-9313. ВІСНИК КНТЕУ. 2021. 
38. Барановський О. І. Філософія безпеки: монографія: у 2 т. Київ: УБС НБУ, 2014. Т.1: Основи економічної і фінансової безпеки економічних агентів. $831 \mathrm{c}$.

39. Капустін М. Про деякі проблеми економічної безпеки підприємництва. URL: www.personal.in.ua/article.php?ida $=524$.

40. Шкарлет С. М. Економічна безпека підприємства: інноваційний аспект: монографія. Київ: Книжкове вид-во Національного авіаційного ун-ту, 2007. 436 с.

Стаття надійшла до редакиії 16.12.2020.

Zubko T. Genesis of the concept of "economic security of the enterprise".

Background. At the initial stage of theoretical research, it is necessary to investigate thoroughly the evolution of the concept "Economic security of the enterprise".

Analysis of recent researches and publications. The issue of economic security of the enterprise (ESE) is one of the most relevant topics of scientific discussion. V. Dykan, K. Bozhko, M. Kopytko, V. Lukianova, M. Kabrik, S. Lekar, R. Skrynkovskyi, I. Stoianenko, O. Arefieva, O. Iliashenko, N. Huliaeva and many others deal with the problems of economic security at the micro level. However, despite the significant interest of domestic and foreign scientists and practitioners, a unified approach to the definition of the term "economic security of the enterprise" has not yet been developed, and existing approaches differ in some emphasis on resource constraints.

The aim of the article is to explore the stages of formation of the category "economic security", to identify approaches to the definition of economic security and to reveal the essence of the concept of "economic security of the enterprise".

Materials and methods. The basis of this article is a synthesis of research results of domestic and foreign scientists to determine the categories of "economic security" and "economic security of the enterprise". Methods of theoretical generalization, analysis and synthesis have been used in this research.

Results. The article shows the essence and evolution of the concept of economic security. The definition of safety given by American and British scientists has been studied. Formation stages of the category "economic security" are considered, the approaches to the definition of the concept of "economic security of the enterprise" are systematized and grouped. The essence of the concept of "economic security of the enterprise" is revealed. The main essential characteristics of the concept of "economic security of the enterprise" are singled out and specified.

Conclusion. The definition of economic security of the enterprise with the main emphasis on its competitiveness has been stated, taking into account the ability to develop and maintain resource potential. The approaches to determining the essence, nature and features of ESE are studied. Given the wide range of interpretations and diversity of approaches, it is determined that the use of two complementary approaches (strategic and integrated) justifies the definition of ESE. The essential characteristics of the studied definition have been supplemented.

In perspective, the issues of ensuring a sufficient level of economic security of enterprises and strategies for their development should be the subject of a thorough research. The possibilities of system analysis should be combined with the advantages of traditional macro- and microeconomic analysis, which will significantly increase their value.

Keywords: security, economic security, economic security of the enterprise, approaches, types of economic security economic security.

\section{REFERENCES}

1. Dykan V. L., \& Bozhko K. M. (2018). Strategiya zabezpechennya ekonomichnoyi bezpeky promyslovyh pidpryyemstv [Strategy for ensuring the economic security of industrial enterprises]. Visnyk ekonomiky transportu i promyslovosti - Bulletin of Transport Economics and Industry, 63, 150-158. Retrived from http://nbuv.gov.ua/ UJRN/Vetp_2018_63_20 [in Ukrainian]. 
2. Kopytko, M. I. (2015). Ekonomichna bezpeka pidpryiemstv z vyrobnytstva transportnykh zasobiv [Economic security of the enterprises for the production of vehicles]. Kyiv: Liha-Pres [in Ukrainian].

3. Smit, A. (2018). Doslidzhennia pro pryrodu i prychyny bahatstva narodiv [Research on the nature and causes of the wealth of nations]. Kyiv: Nash format [in English].

4. Lukianova, V. V., \& Shutiak, Yu. V. (2014). Diahnostyka ekonomichnoi bezpeky pidpryiemstva [Diagnostics of economic security of the enterprise]. Khmelnitsky: KhNU [in Ukrainian].

5. Cabric, M. (2015). Corporate Security Management: Challenges, Risks, and Strategies. Butterworth-Heinemann [in English].

6. Lekar, S. (2019). Pravove rehuliuvannia ekonomichnoi bezpeky v Ukraini [Legal regulation of economic security in Ukraine]. Pidpryiemnytstvo, hospodarstvo i pravo Entrepreneurship, economy and law, 12, 186-193. Retrived ttp://pgp-journal.kiev.ua/archive/ 2019/12/36.pdf. DOI https://doi.org/10.32849/2663-5313/2019.12.35 [in Ukrainian].

7. Skrynkovskyi, R. M. (2015). Ekonomichna bezpeka pidpryiemstva: sutnist, klasyfikatsiia ta systema diahnostyky [Economic security of the enterprise: essence, classifycation and system of diagnostics]. Nikolaev national university of them. Issue 3.414-418 [in Ukrainian].

8. Stoyanenko, I. V., \& Lubenecz' A. O. (2019). Vply'v didzhy'talizaciyi na diyal'nist' ta ekonomichnu bezpeku pidpry'yemstv torgivli [The impact of digitalization on the activities and economic security of trade enterprises]. Molody'j vcheny'j - A young scientist, 1(65), 516-519 [in Ukrainian].

9. Aref'yeva, O. V., Mizyuk, S. G., \& Rashhepkin M. D. (2018). Osobly'vosti formuvannya ekonomichnogo potencialu pidpry'yemstv iz pozy'cij ekonomichnoyi bezpeky' [Features of formation of economic potential of enterprises from the standpoint of economic security]. Naukovy'j visny'k Uzhgorods'kogo nacional'nogo universy'tetu - Scientific Bulletin of Uzhhorod National University, 22, 5-9.Retrived from http://www.visnykeconom.uzhnu.uz.ua/archive/22_1_2018ua/3.pdf [in Ukrainian].

10. Illiashenko, O. V. (2015). Pobudova systemy ekonomichnoi bezpeky pidpryiemstva: pryntsypovi polozhennia [Construction of the system of economic security of the enterprise: principles of position]. Technology audit and production reserves, 5/6(25), 4-7. Retrived from http://journals.uran.ua/tarp/article/download/51252/47246. DOI: 10.15587/23128372.2015.51252 [in Ukrainian].

11. Huliaieva, N. M. \& Vavdiichyk I. M. (2017). Ekonomichna bezpeka ta stabilne funktsionuvannia pidpryiemstva [Economic security and stable functioning of the enterprise]. Visnyk Kyi'vs'kogo nacional'nogo torgovel'no-ekonomichnogo universytetu - Herald of Kyiv National University of Trade and Economics, 4 (114), 79-88 [in Ukrainian].

12. Baldwin, D. A. (1997). The Concept of Security. Review of International Studies. 23, 5-26 [in English].

13. Buzan, B., Waever, O., \&Wilde, J. de. (1998). Security: A New Framework for Analysis. Lynne Rienner Publishers [in English].

14. Neu, C. R. (1994). The Economic Dimensions of National Security. RAND, 86.

15. Richard, H. Ullman (1983). Redefining Security. International Security, 8, 129-153. Retrived from https://muse.jhu.edu/article/446023/summary [in English].

16. Logutova, T. G. (2013). Economic security of industrial enterprises. Ministry of Education and Science of Ukraine. State higher education. institution "Priazov. state tech. un-t". Mariupol: PSTU [in Ukrainian].

17. Mal'tseva, R. YU. (2004). Finansova bezpeka pidpryyemstva: teoriya pytannya [Financial security of the enterprise: theory of question]. Naukovyy visnyk Chernivets'koho torhovel'no-ekonomichnoho instytutu KNTEU - Scientific herald of Chernivtsi trade and economic institute of KNUTE. Issue. II, 158-165 [in Ukrainian].

18. Yepifanov, A. O., Plastun, O. L., \& Dombrovs'kyy, V.S. (2009). Finansova bezpeka pidpryyemstv i bankivs'kykh ustanov [Financial security of enterprises and banking institutions]; A. O. Yepifanova (Ed.). Sumy: UABS NBU [in Ukrainian]. 
19. Dykyy, A. P. (2009). Orhanizatsiya bukhhalters'koho obliku yak instrument zabezpechennya ekonomichnoyi bezpeky pidpryyemstva: avtoref. dys. Na zdobuttya nauk. Stupenya kand. ekon. nauk: spets. 08.00.09 - Organization of accounting as a tool for ensuring economic security of the enterprise: abstract of the dissertation for the degree of Candidate of Economic Sciences: specialty 08.00.09. Zhytomyr: ZHDTU [in Ukrainian].

20. Otenko, I. P., Ivashchenko, H. A., \& Voronkov, D.K. (2012). Ekonomichna bezpeka pidpryiemstva [Economic security of the enterprise]. Kharkiv: KhNEU [in Ukrainian].

21. Omelianovych, L. O., \& Dolmatova, G. E. (2005). Ekonomichna bezpeka torhovelnoho pidpryiemstva [Economic security of trade enterprise]. Donetskyi derzh. un-t ekonomiky i torhivli im. M.Tuhan-Baranovskoho. Donetsk [in Ukrainian].

22. Loktyonova, Yu. A. (2013). Mekhanyzm ydentyfykatsyy sostoianyi ekonomycheskoi bezopasnosty predpryiatyia [The mechanism of identification of states of economic security of the enterprise]. Zhurnal Sotsyalno-ekonomycheskye yavlenyia y protsessu - Journal of Socio-Economic Phenomena and Processes. Issue 5 (051). 129-133 [in Ukrainian].

23. Popovych, P. (2002). Ekonomichna bezpeka pidpryiemstva na suchasnomu etapi rozvytku ekonomiky Ukrainy [Economic security of the enterprise at the present stage of development of the economy of Ukraine]. Visnyk Ternopilskoi akademii narodnoho hospodarstva - Visnyk of Ternopil Academy of National Economy. Issue 2. 93-96 [in Ukrainian].

24. Denysov, O. Ye. (2018). Kompleksnyi pidkhid do otsiniuvannia ekonomichnoi bezpeky haluzi v umovakh hlobalizatsii [Complex approach to assessing of economic security of the industry in the context of globalization]. Biznes Inform - Business Inform, 1, 207-212. Retrieved from http://nbuv.gov.ua/UJRN/binf_2018_1_31 [in Ukrainian].

25. Kuznetsova, I., \& Kiune, O. (2016). Suchasni pidkhody do vyznachennia ekonomichnoi bezpeky pidpryiemstva [Modern approaches to determining economic security of the enterprise]. Visnyk Odeskoho natsionalnoho ekonomichnoho universytetu - Bulletin of the Odessa National University of Economics, 1, 122-135. Retrieved from http://dspace.oneu.edu.ua/ jspui/bitstream/123456789/5246/1/\%Modern\%20approaches $\% 20$ to $\%$ 20determining\% 20economic $\%$ 20security\% 20enterprise.pdf [in Ukrainian].

26. Reverchuk, N. Y. (2004). Upravlinnia ekonomichnoiu bezpekoiu pidpryiemnytskykh struktur [Management of economic security of business structures]. Lviv: LBI NBU [in Ukrainian].

27. Pukhalska, H. V., \& Khrystych, H.O. (2008). Ekonomichna bezpeka pidpryiemstva: sutnist ta yii skladovi [Economic security of the enterprise: essence and its components]. Visnyk Khmelnytskoho natsionalnoho universytetu. Ekonomichni nauky - Visnyk of Khmelnytskyi National University. Economic sciences, 6. (Vol.1). 197-200 [in Ukrainian].

28. Zatserklianyi, M. M., Melnykov, O. F. (2009). Osnovy ekonomichnoi bezpeky [Fundamentals of economic security]. Kyiv: KNT [in Ukrainian].

29. Ivaniuta, T. M., \& Zaichkovskyi, A. O. (2009). Ekonomichna bezpeka pidpryiemstva [Economic security of the enterprise]. Tsentr uchbovoi literatury [in Ukrainian].

30. Zubok, M. I., Krehul, Yu. I., \& Bank, R. O. (2014). Komertsiina rozvidka ta vnutrishnia bezpeka na pidpryiemstvi [Commercial intelligence and internal security at the enterprise]. Kyiv: KNUTE [in Ukrainian].

31. Verkhohliadova, N. I., Herasymova, O. L. Shchehlova, O. Iu., \& Levchynskyi, D. L. (2011). Ekonomichna diahnostyka [Economic diagnostics]. Dnipropetrovsk: Svidler [in Ukrainian].

32. Nusinova, O. V. (2012). Osnovy otsinky ekonomichnoi bezpeky pidpryiemstv: teoretychni ta praktychni aspekty [Fundamentals of economic security assessment of enterprises: theoretical and practical aspects]. M-vo ekon. rozvytku ta torhivli Ukrainy. Kyiv: PanTot [in Ukrainian].

33. Caralli, R. F. \& Wilson, W. R. (2001). The Challenges of Security Management. Pittsburg: CERT. Software Engineering Institute Carnegie Mellon University. Retrieved from http://www/cert.org/archive/pdf/ESM_challenges.pdf [in English]. 
34. Andrushkiv, B. M., Maliuta, L. Ya., \& Pohaidak, O. B. (2016). Adaptyvna strukturnokomponentna model zabezpechennia ekonomichnoi bezpeky pidpryiemstva [Adaptive structural-component model of economic security of the enterprise] Ekonomichnyi analiz - Economic analysis, 2, 42-50. Retrieved from http://nbuv.gov.ua/UJRN/ecan_2016_25\%282\%29_7 [in Ukrainian].

35. Cheberiako, O. V. \& Koshembar, L. O. (2019). Metodolohichni zasady otsiniuvannia ekonomichnoi bezpeky pidpryiemstva [Methodological principles of assessing economic security of the enterprise]: zb. nauk. pr.: O. Yatsenko (Ed.). Kyiv: KNEU. Issue 20. 156-175 [in Ukrainian].

36. Lohinova, N. I. (2009). Mistse kadrovoi bezpeky v ekonomichnii bezpetsi pidpryiemstva [The place of personnel security in economic security of the enterprise] - Kommunalnoe khaziaistvo horodov: Nauchno-tekhnycheskyi sbornyk-Communal economy of cities: Scientific and technical collection, 87, 371-376 [in Ukrainian].

37. Shkaraban, S. I., Koretskyi, B. M., \& Yaroshchuk, O. V. (2010). Diahnostyka i prohnozuvannia finansovo-hospodarskoho rozvytku aktsionernoho tovarystva [Diagnostics and forecasting of financial and economic development of a joint stock company: Ternop. nats. ekon. un-t. 2 ed. Ternop.: TAIP: Rada [in Ukrainian].

38. Baranovskyi, O. I. (2014). Filosofiia bezpeky [Philosophy of security]. Kyiv: UBS NBU. T.1. Osnovy ekonomichnoi i finansovoi bezpeky ekonomichnykh ahentiv [Fundamentals of economic and financial security of economic agents [in Ukrainian].

39. Kapustin, M. (2014). Pro deiaki problemy ekonomichnoi bezpeky pidpryiemnytstva [On some problems of economic security of entrepreneurship]. Retrieved from www.personal.in.ua/article.php?ida=524 [in Ukrainian].

40. Shkarlet, S. M. (2007). Ekonomichna bezpeka pidpryiemstva: innovatsiinyi aspekt: monohrafiia [Economic security of the enterprise: innovative aspect]. Kyiv: Knyzhkove vydavnytstvo Natsionalnoho aviatsiinoho un-tu [in Ukrainian]. 